\title{
Пионеры синтеза ионообменных материалов. 120 лет со дня рождения Александра Борисовича Даванкова (1899-1971)
}

\author{
Рыбакова Е.В. \\ МПО «Абакус», Москва \\ Поступила в редакцию 19.02.2019 г.
}

DOI: https://doi.org/10.17308/sorpchrom.2019.19/744

Представлена история создания отечественных ионообменников с конца 1930 гг. по начало 1970 гг. на основе анализа работ лаборатории ионитов МХТИ им. Д.И. Менделеева. Представлена биография Александра Борисовича Даванкова - одного из отечественных пионеров ионного обмена, а также ранее неизвестные факты биографий и научные работы некоторых ученых, внесших заметный вклад в данную область. Впервые проанализированы ключевые публикации и патенты этого периода с историко-научной точки зрения.

Ключевые слова: история ионообменных сорбентов, история хроматографии, история ионного обмена, биография А.Б. Даванкова.

\section{Pioneers of synthesis of ion-exchange materials. 120 years since the birth of Alexander Borisovich Davankov (1899-1971)}

\author{
Rybakova E.V. \\ $M R O$ «Abacus», Moscow
}

\begin{abstract}
Alexander Borisovich Davankov was born in 1989 as a 13-th child in a peasant's family. Without receiving any systematic basic education, he finally managed to graduate from the 2nd Moscow University (1929) as a specialist in organic chemistry. Since then he was working in the Mendeleev Institute of Chemical Technology. Starting as a leader of a team that worked on oxidation of paraffins and synthesis of various plastic materials he worked up to the position of a Head of Department for anion exchanging resins. Under the leadership of A.B. Davankov in the time period from the middle 1940th to the year 1970 more than 60 original ion exchange resins were developed. Production technology of the most prospective brands was systematically optimized on a pilot-scale plant and resins were manufactured for the use in various areas as waste water purification from phenolic contaminants, recovery of gold and silver from technological solutions in jeweler industry, isolation of gold and uranium from sea water and many others. A.B. Davankov thus happened to be one of the first and most successful specialists in ion exchange in the Soviet Union. Initially he developed a series of ion exchange resins by polycondensation of formaldehyde with urea, melamine and guanidine. Besides effective adsorption of phenol contaminants, these products were found to selectively bind heavy metal ions acting as complex-forming resins. Similar properties were also found to characterize very first amphoteric resins. Later on, Davankov and co-workers suggested a series of efficient anion exchange resins based on polymers of vinylpyridines and cation and anion exchangers based on phosphorylated polystyrene copolymers. Suggestions of concentrating very large amounts of gold in a selective resin column by repeated sorption and electro-reduction cycles was the beginning of redox-type processes and materials. A. B. Davankov is the author of several monographs, textbooks, over 200 scientific articles, 50 patents, two popular-scientific brochures. He was lecturing in technology of cellulose-based and polymeric materials, ion
\end{abstract}


exchange resins. For his outstanding pioneering achievements A.B. Davankov was awarded several important state decorations.

Former students and co-workers of A. B. Davankov thankfully preserve many ironic poems composed by their teacher on the occasion of various festive events of the team. Also, the paper provides basic information about other research groups that were active in the field of ion exchange in the same period of time.

Keywords: history of ion-exchange resins, chromatography history, history of ion-exchange, biography of Alexander Davankov.

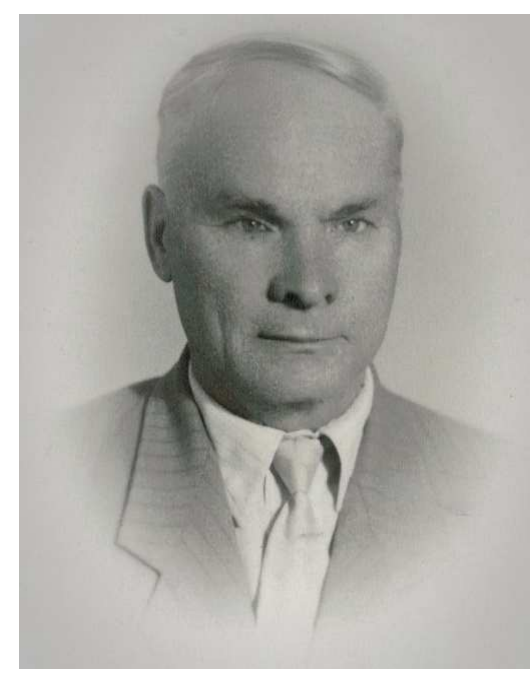

А.Б. Даванков

19 марта (6-го по ст.с) 1899 г. в большой крестьянской семье в селе Поздном Михайловского уезда Рязанской губернии родился выдающийся химикполимерщик, педагог и популяризатор науки, посвятивший всю свою жизнь ионообменным материалам - Александр Борисович Даванков. (Рис. 1)

Благодаря самообразованию, целеустремленности и упорству в 1921 г. А.Б. Даванков поступил во 2-й Московский государственный университет на химико-фармацевтический факультет, где ректором был профессор, зав. кафедрой органической химии Сергей Семенович Наметкин. Один немаловажный факт может раскрыть истоки будущих научных интересов Даванкова. С 1927 г. С.С. Наметкин начал читать студентам курс химии нефти. В то время он разрабатывал технологии нефтехимического синтеза, в частности, окисления парафина, получения моющих средств и др. Можно сделать предположение, что именно этот курс определил выбор направления дальнейшей научной деятельности Даванкова. А.Б. Даванков считал своим учителем не только Наметкина, но и Владимира Михайловича Родионова, в 1920 гг. он был профессором 2-го МГУ по кафедре химии алкалоидов и в то же время состоял профессором МВТУ. Возможно, благодаря Родионову с августа 1928 г., параллельно с учебой во 2-м МГУ, А.Б. Даванков начал работать в МВТУ на кафедре жиров и масел. Университет А.Б. Даванков окончил в 1929 г. по специальности «химик-органик», защитив работу «Действие цианистого калия на меконин» [1] под руководством B.М. Родионова. 1920-1930-е гг. были нелегкими как для учащихся, так и для преподавательского состава. Но, несмотря на революционные преобразования в том числе в системе образования, именно химико-фармацевтический факультет отличал высокий теоретический уровень подготовки и сочетание учебной работы с практической и научной, чему способствовали выдающиеся учёные и педагоги - в первую очередь C.C. Наметкин и В.М. Родионов, создавшие новые научные направления, а также Абрам Моисеевич Беркенгейм. Последний заведовал кафедрой химии синтетических лекарственных средств, читал курсы общей и аналитической химии на основе электронной теории строения материи, также заведовал лабораторией. Он считал, что для подготовки хорошего специалиста-химика недостаточно обучить его работе в лаборатории, поэтому вложил собственные средства в организацию при лаборатории полузаводской установки, на которой проходили обучение все его студенты. В целом к 1930 гг. А.Б. Даванков получил не только блестящее и разностороннее образование, он приобрел опыт работы на химическом производстве и научных исследований.

В 1929-1933 гг. проводилась кампания по реорганизации химических вузов, в которую были вовлечены Химический факультет МВТУ, Химико-фармацевтический 
факультет 2-го МГУ и Химический факультет МГУ, все они были филиалами Единого Московского химико-технологического института имени Д. И. Менделеева. В результате чего, в частности, в апреле 1930 г. кафедра технологии жиров и эфирных масел МВТУ (зав. каф. П.А. Мошкин) влилась в аналогичную кафедру МХТИ, вместе с кафедрой был переведен в МХТИ и Александр Борисович [2] на должность ассистента. На кафедре «группа окислителей», под руководством А.Б. Даванкова [3, С.21], занималась окислением углеводородов нефти (в частности, парафина) до жирных кислот на опытной установке, «обкатывая» различные технологии. Работа над установкой была начата еще в МВТУ, затем продолжена в МХТИ. О научной деятельности Александра Борисовича того времени можно судить по патенту, заявленному 17 ноября 1930 года П. А. Мошкиным и А. Б. Даванковым: «Способ разделения кислот, полученных при окислении углеводородов». Авторы разработали способ разделения оксикислот по принципу растворимости в петролейном эфире. [4]

На базе кафедры технологии жиров и эфирных масел МХТИ в конце 1932 г была создана кафедра технологии пластмасс (ХТП). Группа окислителей продолжала работать на новой кафедре вплоть до 1939 г., в ее состав входили: А. Б. Даванков, О. Я. Федотова, Н.И. Антропова, А. П. Григорьев и др. [5]. Ольга Яковлевна Федотова и Алексей Петрович Григорьев, как и Александр Борисович всю свою жизнь свяжут с МХТИ. Опытная установка, проработавшая в МХТИ до 1935 г., легла в основу проектирования больших производств, в частности, Шебекинского химкомбината, который запустили уже после войны, в конце 1940 гг. [6]. Специфика научной работы кафедры с момента ее организации состояла в том, что осуществлялась она в основном по линии хоздоговоров с различными организациями. Т.е. государство в интересах производственников ставило перед кафедрой задачи обеспечения нужд промышленности.

А.Б. Даванков по приглашению зав. кафедрой профессора Ивана Платоновича Лосева, вместе с профессором Григорием Семеновичем Петровым принимал активное участие в становлении новой кафедры. [3, С.45] Даванков организовал и бессменно вел лабораторный практикум по технологии пластмасс и целлюлозных пластиков. 7 марта 1934 г. А.Б. Даванков был утвержден в должности доцента [1]. В те годы он продолжал заниматься технологией получения синтетических жирных кислот, начав первые опыты по получению пластмасс. 30 марта 1935 года А. Б. Даванковым, А. П. Григорьевым, И. П. Лосевым, С. В. Шишкиным и О. Я. Федотовой был заявлен способ получения пластической массы для звукозаписи с применением солей жировых кислот - продуктов окисления нефтяных углеводородов [7]. В то же время Г.С. Петровым и А.Б. Даванковым велась разработка технологии пластической массы, которую называют искусственным воском [8].

Высокий научный уровень работ А.Б. Даванкова позволил ему получить 29 ноября 1935 г. ученую степень кандидата технических наук без защиты диссертации. Из книги О.Я. Федотовой об истории кафедры ХТП узнаем, что в 1936 г. А.Б. Даванков был руководителем, а Н.И. Антропова исполнителем хоздоговорной работы с Главхимпластмасс «Разработка пластика на основе активного ила». [3, С.40] «Опыты Даванкова и Антроповой по получению пластмасс с использованием активного ила дали положительные результаты и были проверены на ряде заводов». [9, с.502-503] Результаты этой работы были также оформлены патентом, заявленным в 17 марта 1940 года в Народный комиссариат коммунального-хозяйства РСФСР. [10] К этим работам А.Б. Даванков и Н.И. Антропова вернулись в 1947 г., в тот год в Трудах МХТИ вышли три статьи, посвященные использованию бактериальных белков из активного ила для получения пластмасс, а также изучению их свойств. 
В 1937 г. выходит первый вариант учебного пособия А.Б. Даванкова «Лабораторные работы по химии целлюлозы и целлюлозных пластиков», напечатанный типографией МХТИ. Его второе издание, вышедшее в 1939 г. [11], представляет собой обстоятельный труд, с обширным литературным обзором. В нем описаны основные методы лабораторного получения, анализа и испытаний различных препаратов целлюлозы, ее эфиров, пластификаторов, пленок и пластмасс. Книга служила пособием не только для студентов, но и для специалистов в области лаков, красок и искусственного волокна; она сохраняет свою ценность и в настоящее время.

Из нескольких источников известно, что уже в 1938г. на кафедре начались исследования в области синтеза и применения ионообменных материалов. [3, С.27, 40; 12 , C.47]. В то время только недавно образованный Всесоюзный научноисследовательский институт водоснабжения, канализации, гидротехнических сооружений и инженерной гидрогеологии (ВОДГЕО) работал над задачами очистки вод для водоснабжения городов и промышленных предприятий. Кафедре ХТП по хоздоговору с ВОДГЕО требовалось провести исследования по синтезу и применению полимеров для анионного и катионного обмена для целей водоочистки. В данном исследовании приняли участие Г.С. Петров (руководитель), А.П. Григорьев, А.Б. Даванков, И.П. Лосев, однако работы по этому хоздоговору были прерваны войной.

В 1940 г. МХТИ праздновал свое 20-тилетие, изданная по этому случаю книга содержит описание специальностей кафедр, включая кафедру ХТП. Кафедра «готовит инженеров для производств: а) пластмасс и аналогичных продуктов из эфиров целлюлозы... б) пластмасс, получаемых в результате реакций конденсации...; в) полимеризационных смол типа полистирола, поливинила, метакрилата....г) белковых пластмасс... д) пластмасс и композиций на основе асфальта, битумов и сходных продуктов; е) вспомогательных продуктов и пластификаторов ...; ж) изделий из пластмасс и композиций, в том числе и граммофонных пластинок, электроизоляционных материалов и т.д.». [5] Очевидно, что нет ни одной специальности по которой бы не было работ А.Б. Даванкова. К 1940 г. (за 8 лет существования) кафедра выпустила 243 инженера-технолога. Преподавательский состав кафедры на этот момент: зав каф., д.т.н. И.П. Лосев, проф. Б.Н. Рутовский, доц. А.Б. Даванков. Кафедра ХТП располагала: лабораторией (пл. 434,7 м²), опытной установкой и прессовой установкой.

Из-за наступления немцев на Москву, в октябре 1941 г. институт с сотрудниками и их семьями был эвакуирован в г. Коканд Узбекской ССР. Эвакуировалась и кафедра пластмасс, включая зав. кафедрой И.П. Лосева и А.Б. Даванкова с семьями, а также студенты и аспиранты. Сразу по прибытию в Коканд начались занятия. Лосев читал лекции по высокомолекулярным соединениям, а Даванков вел лабораторные занятия [13]. Однако важно, что кафедра параллельно развернула научнопрактическую работу по заданиям Союзного и Узбекского правительств. Под руководством И.П. Лосева и А.Б. Даванкова в Коканде в небольшой мастерской была запущена установка по извлечению жира из отходов шелкомотального производства, позднее установка была передана на шелкомотальную фабрику. Другая их совместная работа- разработка способа получения конторского клея. Для местного кожевенного завода А.Б. Даванков разработал и внедрил в производство водноэмульсионный метод жирования кож с заменой пищевых жиров минеральными маслами. Освободившийся в результате рационализации технологического процесса запас хлопкового масла был использован для питания рабочих. [13] В то же время А.Б. Даванков разработал способ получения удобрений из отходов серного рудника, находившегося в окрестностях Коканда, что дало экономический эффект для кафедры 
и института. [3, С.28] Сотрудники кафедры, включая А.Б. Даванкова, проводили и другие исследовательские работы, связанные с рациональным использованием отходов местных производств для нужд фронта и тыла.

В личном деле имеется характеристика от декабря 1942 г., на доцента А.Б. Даванкова, где указано, что он исполняет обязанности зав. кафедрой технологии пластмасс. К этому документу приложена характеристика на А.Б. Даванкова, написанная Г.С. Петровым, где он резюмирует, что Даванков «способен самостоятельно возглавлять кафедру» [1].

В марте 1943 г А.Б. Даванков в должности временно исполняющего обязанности заведующего кафедрой пластмасс, вместе с другими сотрудниками кафедры, возвратился из эвакуации в Москву. В то же время Московский филиал кафедры, который образовался в 1942 г., возглавлял Г.С. Петров. По всей видимости, ученое звание кандидата наук послужило препятствием назначению Даванкова заведующим кафедрой. В итоге Даванков и несколько сотрудников «довоенной кафедры», включая А.П. Григорьева, продолжили работать уже под руководством Петрова, на кафедру пришли недавние выпускники - Н.Е. Огнева и др. Важно отметить, что в том же 1943 г. был образован Научно-исследовательский институт пластмасс (НИИПМ), в котором заместителем директора по научной части, а затем и директором (19461949) работал Г.С. Петров [11]. И.П. Лосеву по возвращении в Москву предоставили другую кафедру, и к нему перешла часть сотрудников, в частности Е.Б. Тростянская, а также выпускники кафедры ХТП: А.С. Тевлина и др.

Научно-исследовательские работы Даванкова военных лет, видимо по причине секретности или условиям хоздоговоров, не были опубликованы. Только об одной из них мы можем судить по патенту «Способ поверхностной защиты материалов и изделий», заявленному 5 ноября 1943 года [14]. Авторы патента для поверхностной защиты материалов и изделий предлагают обрабатывать поверхность карбамидными смолами, после чего вторым слоем наносить покрытие из фенолальдегидной смолы. «Предложенный способ комбинированного покрытия ... разрешает вопрос о защите металлических и неметаллических изделий от действия влаги, химических реагентов и органических растворителей». Можно только догадываться, но скорее всего это была работа по заказу военных. Заслуги А.Б. Даванкова были оценены по достоинству - 19 декабря 1945 г. по решению Президиума Верховного Совета СССР ему была присуждена медаль «За доблестный труд во время Великой отечественной войны 1941-1945 гг.».

По данным О.Я. Федотовой, начиная с 1945 г. в соответствии с индивидуальным планом, доцент Даванков отвечал за «синтез ионообменных смол для очистки воды и различных отходов» [3, С.28]. Кроме того, он читал студентам курс технологии пластмасс на основе эфиров целлюлозы, по воспоминаниям Л.Б. Зубаковой (выпускница кафедры ХТП 1950 г.) [15, С.103]. В 1946 г. вышла монография Г.С. Петрова, Б.Н. Рутовского и И.П. Лосева «Технология синтетических смол и пластических масс» [9], третья часть этой монографии - «Белковые пластмассы» написана Даванковым. Книга была сдана в набор в августе 1945 г, примечательно, что в ней только однажды упоминается об ионообменных свойствах синтетических смол, в главе, написанной Г.С. Петровым: «Сравнительно недавно установлено, что неплавкие продукты конденсации многоатомных фенолов или аминов с альдегидами могут быть использованы для анионного и катионного обмена при очистке жесткой воды или при удалении из водных растворов некоторых солей металлов» [9, с.28-29] Возможно с этой строчки в монографии и началось дело всей жизни Александра Борисовича, поскольку вскоре, в 1946 г. была образована проблемная лаборатория ионитов $[13$, С.95], которой он руководил до конца своих дней. С этого времени основ- 
ным направлением его научно-исследовательских работ стал синтез, исследование и применение ионообменных смол. Его надежным помощником и соавтором по многим последующим научным работам была м.н.с. Вера Моисеевна Лауфер (19001973).

9 декабря 1946 г. в Министерство химической промышленности СССР была подана заявка на изобретение, зарегистрированная за №996-46 (350289), «Способ получения синтетических смол», патент был опубликован 30 апреля 1948 г. Авторы: Г.С. Петров, А.Б. Даванков, В.М. Лауфер. «Предмет изобретения: способ получения синтетических смол, пригодных для анионного обмена, на основе метафенилендиамина и альдегидов, отличающийся тем, что метафенилендиамин, как таковой, или совместно с дифенилгуанидином, или азотнокислым гуанидином конденсируют с формальдегидом и масляным альдегидом с целью получения смолы, обладающей высокой емкостью». [16] «Настоящее изобретение касается разработки новых методов получения весьма активных модифицированных аминосмол для извлечения кислот из различных жидкостей и растворов. Эти смолы по своей емкости (способности поглощения кислот) в 2-3 раза превосходят применявшиеся для этой цели смолы на основе метафенилендиамина и формальдегида. Кроме того, по своей химической структуре они отличаются большей устойчивостью к окисляющему действию кислорода, а следовательно, и более устойчивы в отношении старения». Обратив внимание на фразу «применявшиеся для этой цели смолы на основе метафенилендиамина и формальдегида», мы провели дополнительное расследование. В статье сотрудника ВТИ (Всероссийский теплотехнический институт) Ф.Г. Прохорова [17], опубликованной в 1955 г. в сборнике «Теория и практика применения ионообменных материалов», посвященной исследованию старения ряда анионитов в результате их окисления, мы узнаем, что в 1939 г. в ВТИ был синтезирован анионит «аминосмола ВТИ», который изготавливался в промышленном масштабе в 1940 г. Аминосмола ВТИ представляет собой «продукт конденсации метафенилендиамина с формалином». Кроме того, имеется указание, что изучение старения аминосмолы было проведено автором в 1945-1947 гг. (т.е. в то же время, когда Даванков создавал свой анионообменник более устойчивый к окислению кислородом), а другие иониты, рассматриваемые в данной статье: вофатит МД, аниониты АН-1Ф, АН-4К, и АН-7К бЫли исследованы Ф.Г. Прохоровым в 1952 г. Кто был автором «аминосмолы ВТИ» пока обнаружить не удалось. В любом случае в 1946 г. появился первый в СССР патент на способ получения ионообменника, и, таким образом, можно утверждать, что Александр Борисович был одним из пионеров синтеза отечественных ионитов на полимерной основе.

Характеристики, написанные на А.Б. Даванкова на протяжении 1945 - 1947 гг. говорят о том, что его неоднократно выдвигали на руководство кафедрой. В отзыве Г.С. Петрова прямо указано: «По опыту и стажу своей квалификации А.Б. Даванков перерос масштабы работ, выполняемых им на кафедре и может быть выдвинут на более ответственную педагогическую или научно-исследовательскую работу» [1].

В 1947 г. по приказу Министерства высшего образования была организована кафедра технологии высокомолекулярных соединений (ТВМС), которую возглавил И.П. Лосев. Лосев читал курс химии ВМС для студентов обеих кафедр (ХТП и TВMC). Так были созданы кафедры по существу сходного профиля и похожим учебным планом. Интересная ситуация сложилась с тематикой ионообменных материалов: руководители кафедр договорились, что кафедра ХТП (Даванков) будет заниматься анионитами, а кафедра ТВМС (Лосев) - катионитами.

12 февраля 1948 года Г.С. Петровым, А.Б. Даванковым и В.М. Лауфер был заявлен патент на «Способ получения синтетических смол» [18]. Патент описывает 
способ получения меламино-гуанидинформальдегидных смол (аниониты), обладающих существенно большей емкостью, по сравнению с существующими. Кроме того, в том же году Г.С. Петров, А.Б. Даванков, В.М. Лауфер предложили способ получения ионита, на котором возможно совместить процесс очистки различных веществ от электролитов с одновременным удалением из раствора красящих веществ. [19] Авторы предложили в процессе синтеза вводить добавки (активированный уголь, силикагель и т.п.), «ионообменная способность смол при этом в некоторых случаях увеличивается за счет увеличения активной поверхности смол».

Однако иониты не были исключительной темой работ Даванкова этого периода. Так 10 ноября 1948 г. им был заявлен патент «Способ получения органических пигментов» [20]. Обращает на себя в первую очередь своей оригинальностью патент того же года «Способ получения спичек на основе полимеров» [21]. Авторы патента предложили «способ получения спичек на основе полимеров и, в частности, на основе полиметилметакрилата, отличающийся тем, что полимеры формуют в виде шариков, кубиков или цилиндров и покрывают с поверхности зажигательным составом, приготовленным на клеевой композиции». Изобретение, безусловно, актуально и в наши дни, поскольку «полученные таким способом спички сохраняют способность зажигаться после пребывания в воде в течение нескольких часов».

В этот период группа Даванкова работает над поиском новых анионообменников. Так 4 июля 1949 г. А.Б. Даванковым и С.Я. Борзенковой был заявлен «Способ повышения ионообменной способности мочевино и меламиноформальдегидных смол» [22]. «Способ заключается в проведении реакции конденсации аминов и амидов с альдегидами в сопровождении с реакциями восстановительного или окислительно-восстановительного характера, при которых в смоле сохраняется значитель-

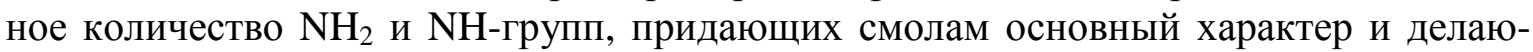
щих их активными в отношении анионного обмена».

Известно, что с 1949 г. Г.С. Петров совместно с новым директором НИИПМ М.А. Акутиным начинают развивать исследования и разработки, в том числе в области поликонденсационных ионообменных смол. [11, С.63] Эти работы в НИИПМ выполнялись К.М. Салдадзе. С 1955 г. официально к ним присоединился А.Б. Пашков, однако фактически уже в 1949 г. разработанный А.Б. Пашковым самый известный отечественный катионит КУ-2 был внедрен в производство на предприятии НИИПМ. Дело в том, что Аркадий Борисович Пашков отбывал репрессивное наказание с 1943 г. по 1955 г., с 1947 г. - в ОКБ-4 спецотдела НКВД. С 1949 г. основным направлением его научной и производственной деятельности был синтез ионообменных смол. В своей автобиографии [23] он пишет: «В 1949 был выпущен закрытый полный отчет «Синтез новых катионитов» и технологический регламент, на основе которого на Кемеровском заводе «Карболит» была организована опытная установка по полной схеме по получению катионита КУ-2 мощностью 50 тонн в год». Т.о. можно утверждать, что с 1949 года на предприятиях, подчиняющихся НИИПМ, начинается промышленное производство отечественных синтетических ионитов.

1950 год был насыщен различными событиями. Вышла одна из первых монографий по ионообменникам американских ученых Кунина и Майерса «Ионообменные смолы»[24]. Книга была переведена на русский язык и выпущена в 1952 г. под редакцией Г.С. Петрова. В предисловии к ней он сетует, что «часть материала (в частности касающегося описания заводской аппаратуры) изложена недостаточно обстоятельно» [25].

В 1950 г. начала свою работу лаборатория хроматографии в Институте физической химии АН СССР (ИФХ) под руководством в то время д.Х.н., профессора Константина Васильевича Чмутова, который организовал первое Всесоюзное сове- 
щание по хроматографии, состоявшееся 21-24 ноября 1950 г. Как пишет о докладчиках этого совещания Е.М. Сенченкова: «Авторами заявок стали как уже проявившие себя в хроматографии специалисты (В.В. Рачинский, Т.Б. Гапон, Д.И. Рябчиков, Ф.М. Шемякин, К.В. Чмутов, И.А. Фукс и др.), так и ее новые энтузиасты (А.Б. Даванков, К.М. Салдадзе, Б.Г. Савинов, И.П. Лосев, Е.Б. Тростянская, С.А. Напольский и др.)» [26]. Труды этого совещания были изданы в 1952 г. как сборник «Исследования в области хроматографии»[28].

На этом во всех отношениях эпохальном совещании по хроматографии А.Б. Даванков сделал сообщение, которое затем было помещено в упомянутый сборник в виде статьи под названием: «О связи между строением некоторых аминоформальдегидных смол и их способностью к ионному обмену» [28]. В определенном смысле эту статью можно считать программной, поскольку она отражает текущие работы Даванкова, первые открытия и наметки направления будущих исследований. Автор отмечает, что «ионообменная способность искусственных смол, а также их механические и физико-химические свойства находятся в прямой зависимости от структуры и условий получения ионитовых смол, а между тем, этим вопросам не уделяется должного внимания, ни в журнальных статьях, ни в отдельных монографиях». Главный тезис данной работы заключен в следующем: «решающее влияние на свойства конечного продукта оказывает не исходное сырье, а направление реакции конденсации при синтезе амфотерных ионитовых смол, которые до сих пор не были известны в литературе и которые впервые синтезированы нами в 1949 г. В отличие от широко известных катионитовых и анионитовых смол, амфотерные иониты совмещают в себе свойства тех и других... В зависимости от условий получения, у амфотерных ионитов могут превалировать кислотные или основные свойства». Авторы видят перспективу использования таких смол «при разделении аминокислот и при адсорбции ионов амфотерных элементов». Важно, что в статье приводятся подробные характеристики «одного из образцов амфотерной ионитовой смолы, синтез которого освоен в полузаводских масштабах». Данный ионит исследован на поглощение неорганических анионов, а также ацетата; катионов серебра и натрия и фенола. В заключение авторы отмечают перспективность полимеризационного способа получения «высокоактивных анионитовых смол». Ссылки на три патента на способ синтеза анионообменников за 1949-1950 гг. красноречивее всего говорят об интенсивности работ группы Даванкова.

В том же сборнике помещена статья группы И.П. Лосева «Катионообменные смоляные сорбенты» [29], ее название подтверждает факт разделения направления работ на «катионные» и «анионные» по двум «полимерным» кафедрам МХТИ. Авторы отмечают необходимость «установления химического строения сорбирующей смолы», критически рассматривая представления зарубежных и отечественных исследователей о структурах сульфо- и карбоксильных катионообменников, опровергая их собственными экспериментальными исследованиями. В заключение авторы отчитываются о разработке 10 марок катионообменников: «нами разработаны чистые сульфосорбенты нескольких типов с содержанием серы от 7.4 до 11.3\% (СБС, СДВФ, ДФ) и смешанные, содержащие в своей структуре сульфо- и оксифенильные (МСФ), сульфо- и карбоксильные группы (СМ), а также сорбенты, содержащие только карбоксильные (КМ, КН) или фосфокислые (ФР, ФС) группы». Статья К.М. Салдадзе в том же сборнике, напротив, посвящена «пределам возможностей» отечественных и зарубежных смол: термостойкость, стойкость к кислотам и щелочам при регенерации, стабильность поглотительной способности, набухаемость, а также стойкость к окислителям, таким как перманганат калия [30]. 
3 декабря 1950 г. Министерство химической промышленности вручило А.Б. Даванкову значок «Отличника Химической Промышленности» за подготовку высококвалифицированных инженерных кадров, а 23 декабря 1950 г. А.Б. Даванков награжден значком «Отличник социалистического соревнования» в ознаменование 30тилетия МХТИ.

А 5 ноября 1951 г. по решению Президиума Верховного Совета СССР А.Б. Даванков был награжден орденом Трудового Красного Знамени за безупречную многолетнюю службу.

В начале 1953 г. была создана Комиссия по хроматографии АН СССР, в ее состав (всего 20 чел.) вошли от МХТИ А.Б. Даванков и И.П. Лосев [26]. Александр Борисович до конца жизни принимал активное участие в работе комиссии, а в дальнейшем Научного совета по хроматографии АН СССР.

В 1954 г. в журнале «Гигиена и санитария» выходит статья А.Б. Даванкова и Н.Е. Огневой об очистке промышленных сточных вод от фенола синтезированной ими анионообменной смолой Н-О. [31]. К синтезу специфичных к фенолу сорбентов А.Б. Даванков будет обращаться еще не раз.

В 1955 г. вышел сборник «Теория и практика применения ионообменных материалов» под редакцией чл-корр. АН СССР К.В. Чмутова [32], в предисловии к которому он отметил, что «несмотря на то, что отдельным организациям удалось синтезировать новые марки высокоэффективных ионообменных смол, массовое промышленное их производство до сих пор еще не освоено, что тормозит внедрение методов ионного обмена в народное хозяйство...». В сборнике помещены статья А.Б. Даванкова и три статьи «группы Лосева». Статья А.Б.Даванкова «Об извлечении фенола из водных растворов анионитовыми смолами» отражает текущие работы этой группы по синтезу анионитов и изучению их свойств [33]. В частности, мы узнаем, что «в качестве адсорбентов фенола на полузаводской установке были изготовлены смолы: ММГ-1, МН, ТН, Н-О, Н». Кроме того, были испытаны также анионит ПЭ-9 и катионит СБС, по всей видимости, производимые массово. Постановка задачи извлечение фенола - продиктована целесообразностью возврата фенола из промышленных стоков производств химической промышленности, а также уменьшением загрязнения окружающей среды. Автор рекомендует для извлечения фенолов использовать аниониты Н-О, МН и ПЭ-9, а также отмечает, что «наряду с фенолом ... извлекаются минеральные и органические кислоты».

Если проанализировать сообщения «группы Лосева», то статья Е.Б. Тростянской - это попытка ввести классификацию катионообменных сорбентов по количеству и типу функциональных групп на одно- и полифункциональные «высокомолекулярные нерастворимые поликислоты» [34]. Статья по сути является литературным обзором работ, в основном зарубежных авторов. В сообщении И.П. Лосева, А.С. Тевлиной и Е.Б. Тростянской [35] обсуждаются условия синтеза сульфофенольноформальдегидного сорбента (катионита), с критикой данных, изложенных в сборнике И.Э. Апельцина и др. [36]. Третье сообщение И.П. Лосева [37] чисто практического характера: «лабораторная установка для получения обессоленной воды», содержит практические указания по подготовке и использованию двух таких установок. Одна - стеклянная, которую «можно заказать в стеклодувной мастерской МХТИ», другая изготовлена из винипласта - ее можно заказать на Владимирском заводе Главхимпласт. Рекомендованные сорбенты - катиониты СБС, СБСР, МСФ или СДВ3, аниониты - ММГ или Н-О. Важно, что у авторов имеется уже как минимум 6-ти летний опыт эксплуатации подобных установок, поскольку в заключении статьи отмечается, что «смоляные фильтры могут работать без смены в течение 5-6 лет». 
5 марта 1956 г. А.Б. Даванков и Т. Вехец заявили «Способ получения анионитов» [38] путем превращения сульфокислотных катионообменных материалов обработкой аммиачной водой или аминами, при повышенной температуре и давлении, в анионообменные материалы, минуя стадию нитрования и восстановления нитрогрупп. Авторы отмечают, что «способ особенно эффективен для случая превращения дешевого сульфоугля в аминоуголь. ... Вместо сульфоугля можно применять другие катионообменные материалы СБС, СДВ-3, КУ-2 и др.»

Следует обратить внимание, что, практически с начала работ по ионитам, А.Б. Даванков уделял больше внимания ионообменникам полимеризационного типа, именно такие иониты стали основой промышленных образцов. Начиная с 1956 г., важным направлением исследований лаборатории А.Б. Даванкова становится синтез специфических ионитов, имеющих сродство к драгоценным металлам и урану и разработка процессов их извлечения из сточных и природных вод. В 1956 г. выходят две статьи А.Б. Даванкова и В.М. Лауфер в журнале «Заводская лаборатория», посвященные концентрированию золота и серебра на анионитах Н-O, МН и АН-1. Для извлечения драгоценных металлов предлагалось сжигать смолу. Тогда же А.Б. Даванков и В.М. Лауфер предлагают методики количественного определения драгоценных металлов с применением сорбции на ионитах [39].

В том же 1956 году в Москве Комиссия по хроматографии АН СССР провела специальное совещание с целью выявления возможностей применения ионообменных смол в медицинской и пищевой промышленности. Во вступительном слове Председатель Комиссии по хроматографии чл.-корр. АН СССР К.В. Чмутов отметил большую перспективность и экономическую выгодность применения ионообменных смол, обратил внимание участников совещания на важность производства различных марок ионообменных смол, удовлетворяющих специальным требованиям различных производств. Труды Совещания были изданы в 1957 г. в сборнике «Исследования в области ионообменной хроматографии» [40]. В состав редакционной коллегии сборника, кроме ответственных редакторов К.В. Чмутова и Ф.М. Шемякина, вошли: А.Б. Даванков, В.В. Рачинский, К.М. Салдадзе, П.Л. Сенов, Е.В. Тростянская.

В сообщении А.Б. Даванкова и В.М. Лауфер указанного сборника «О свойствах некоторых видов смол для анионного обмена и возможности их применения в медицине и пищевой промышленности» [41] авторы отмечают, что ими открыта новая группа- амфотерные синтетические ионообменники, описывают их основные характеристики- набухаемость, скорость ионного обмена и т.д., и те факторы (структура, размер частиц, пористость и др.), что оказывают на них влияние. В данной статье приведены характеристики 6 марок анионитов (ММГ-1, МH, ТН, Н, H-O, МПВХ), изготавливаемых на полузаводской установке в лаборатории технологии пластических масс МХТИ. Примечательно, что в статье помещена фотография с восемью сосудами с ионитами, с названиями марок на этикетке. [41, С.131] Перед каждым сосудом на листе бумаги насыпан горкой соответствующий ионит, видимо, чтобы показать их цветовую палитру. Разумеется, черно-белая фотография не может передать действительный цвет материала, однако мы можем понять, что сорбент марки ТН - кипенно-белый, а ММ2Н - практически черный. Авторы отмечают, что анионитовая смола Н-О проходила многочисленные испытания в ВТИ (исп. А.М. Прохорова) и в других лабораториях (исп. В.П. Мелешко) на извлечение кремниевой кислоты, «в комбинации с анионообменной смолой ММГ-1 она рекомендуется в качестве эффективного средства для умягчения воды и полного удаления кремниевой кислоты». Про смолу ММГ-1 авторы пишут, что она «получила широкое распространение в качестве одного из хороших средств для обессоливания воды», ссылаясь на публикацию Д.И. Рябчикова, М.М Сенявина и К.В. Филипповой в ЖАХ. Смола 
ММГ также применялась «для специальных целей по извлечению редких элементов». Говоря о возможностях амфотерных ионитов, авторы предполагают, что они «могут представлять интерес для извлечения и очистки антибиотиков, разделения аминокислот и соединений, склонных к комплексообразованию». Следует отметить, что группа Даванкова синтезировала иониты в значительных количествах. Полупромышленные установки для синтеза размещались в небольшой одноэтажной пристройке к основному корпусу МХТИ, примыкающей к помещениям кафедры ХТП. Авторы сетуют, что несмотря на то, что более 300 различных учреждений: институтов, заводских лабораторий и промышленных предприятий используют их аниониты, редким исключением явилась апробация этих материалов в медицине и пищевой промышленности. Статья в определенном смысле имеет характер рекламной, целью которой было, во-первых, показать возможности и ассортимент анионитов, изготавливаемых в лаборатории А.Б. Даванкова, во-вторых, привлечь специалистов различного профиля для применения ионитов в пищевой и медицинской промышленности.

В том же сборнике в сообщении К.М. Салдадзе, 3.Г. Демонтерик, 3.В. Климовой «К вопросу о поглощении катионов тяжелых металлов анионитами» [42] приводится исследование способности некоторых отечественных анионитов (АВ-17, ЭДЭ10 и др.) к сорбции тяжелых и переходных металлов в виде анионных комплексов. «Описанные новые свойства анионитов имеют не только теоретическое значение, ... но они открывают также новые пути в технологии и аналитике для очистки и разделения различных веществ. При их помощи могут быть очищены концентрированные растворы щелочноземельных и щелочных металлов от тяжелых металлов, они могут служить также для улавливания цветных металлов из растворов с высокими концентрациями солей других металлов, для очистки и разделения некоторых катионов тяжелых, редких и редкоземельных металлов и для других целей». Примечательно, что эти идеи найдут воплощение в дальнейших работах Даванкова. Сообщение Е.Б. Тростянской и А.С. Тевлиной «О свойствах некоторых катионообменных смол и возможности их применения в медицинской и пищевой промышленности» [43] интересно тем, что в нем исследуются возможности ряда отечественных катионообменников, с указанием их организаций-разработчиков. Цель сообщения: «познакомить читателей с характерными свойствами катионообменных смол, разработанных авторами данной статьи (СДВ-3, СБС, КМ, КМД, КМГ), и дать некоторые указания о работе с ними».

В 1957 году ушел из жизни Григорий Семенович Петров и кафедру возглавил Василий Владимирович Коршак, в то время чл. кор. АН СССР. Александр Борисович Даванков, как ветеран кафедры, проработавший с Петровым с момента ее основания, написал брошюру «Григорий Семенович Петров», которая вышла в свет в 1959 г. [44] После кончины Г.С. Петрова, в НИИПМ А.Б. Пашков и К.М. Салдадзе стали развивать новое направление - полимеризационные мембраны. По-видимому, с этих пор тесное научное сотрудничество с ионообменщиками МХТИ существенно ослабло. Однако НИИПМ поручались функции головной научной организации по ряду направлений химической промышленности СССР, в том числе по ионообменным материалам. Необходимо отметить, что К.М. Салдадзе вместе с А.Б. Пашковым внесли большой вклад в организацию промышленности ионообменных материалов. С 1958 по 1963 гг. К.М. Салдадзе [45], а с 1964 г. А.Б. Пашков [23] были Главными химиками по проблеме ионитов в нашей стране, осуществляли научное и организационное руководство производством ионообменных материалов. Следует отдать должное уважение заслугам НИИПМ, поскольку к началу 1990 гг. СССР по производству ионообменных смол занимал 2 место в мире. [11, С 70] 
В 1958 г. после постановления майского пленума ЦК КПСС «Об ускорении развития химической промышленности и особенно производства синтетических материалов и изделий из них для удовлетворения потребностей населения и нужд народного хозяйства» две кафедры наконец объединили свои усилия по синтезу и исследованию свойств ионитов. По всей видимости именно тогда прежняя договоренность о разделе направлений утратила смысл и обе группы объединились под единым началом А.Б. Даванкова. [3, С. 30]. Тогда же. в издательстве московского дома научно-технической пропаганды выходит научно-популярная брошюра А.Б. Даванкова и В.М. Лауфер «Применение ионообменных смол в промышленности».

В 1958 г. появляется патент № 116084 «Способ получения сульфокатионита» [46]. Авторы патента: В.С. Титов, Ф.Т. Шостак, И.В. Самборский, К.М. Салдадзе, В.М. Лауфер, М.В. Виттих, А.Б. Даванков, А.Б. Пашков, П.А. Образцов. Патент описывал оптимизацию технологии получения сульфокатионита на основе сульфопроизводных нафталина с формальдегидом. Этот патент интересен тем, что, во-первых, это пример совместной работы над катионитом НИИПМ и группы А.Б. Даванкова, во-вторых, в составе авторов есть фамилии коллег А.Б. Пашкова по ОКБ-4, занятых разработкой ионитов в конце 1940-х гг.

В 1959 г. комиссия по хроматографии АН СССР издает сборник «Ионный обмен и его применение», в котором размещен обстоятельный обзор (73 страницы, 194 ссылки) «Ионообменные смолы (иониты)», написанный Е.Б. Тростянской с участием А.С. Тевлиной [47]. Целью сборника «дать общий обзор современного состояния синтеза и применения ионитов». В сообщении Тростянской весьма скудно освещена деятельность группы Даванкова, в частности, в разделе, посвященном анионитам отмечается: «высокого качества аниониты получены с применением в качестве исходных веществ для процесса поликонденсации с формальдегидом меламина, мочевины, гуанидина и т.п. (аниониты типа АН-1, ММ-2, НО)...». Есть упоминание о восстановительной способности этих смол. Совсем немного, если обратить внимание, что автор ссылается на 11 сообщений группы И.П. Лосева.

В 1961 г. вышел в свет сборник, посвященный применению сорбентов в промышленности. Как отметил ответственный редактор сборника К.В. Чмутов, несмотря на широкий ассортимент отечественных сорбентов, стране «нужны не просто лабораторные рекомендации, а десятки и сотни тонн сорбентов» [48]. В первом разделе сборника, посвященном получению сорбентов и изучению их свойств, имеются две статьи «группы Лосева» - Е.Б. Тростянской и А.С. Тевлиной с коллегами (одна посвящена способам синтеза катионитов с повышенной избирательностью, другая получению ионообменных мембран) и статья А.Б. Даванкова с Е.В. Замбровской «Синтез и применение высокомолекулярных соединений, содержащих в своем составе тиольные и тионные группы» [49]. В последней авторы отмечают достоинства полимеризационных смол по сравнению с поликонденсационными - высокая стойкость, гранулы правильной сферической формы и др. и предлагают два способа получения специфических сорбентов по отношению к катионам, образующим нерастворимые сульфиды. Катиониты на основе стирола с дивинилбензолом получили обозначение СДТ и СНК. Авторы тестировали иониты на извлечение серебра из 0.1 н растворов нитрата серебра. Процесс сорбции ионов серебра чередовался с восстановлением до металла на ионите. Над этой темой А.Б. Даванков работал с 1959 г., достижения в этой области отражены в патенте [50]. Идея использования окислительно-восстановительных процессов на ионитах для концентрирования благородных металлов получила развитие в статье практического характера [51]. Авторы приходят к выводу, что «чередование ионного обмена с реакциями восстановления или осаждения ... позволяет сконцентрировать в итоге такое количество адсорби- 
руемого вещества, которое в 10-15 раз превышает полную обменную емкость ионита». Авторы исследовали разработанные ими аниониты марок НО и ТН и предложили элюировать золото с анионообменника подкисленными растворами тиомочевины в органических растворителях, в результате ионит восстанавливает свою первоначальную емкость и нет необходимости прибегать к его сжиганию, как это было ранее, что дает колоссальный экономический эффект.

13.09.1961 г. решением ученого совета А.Б. Даванкову предоставляют творческий отпуск для написания докторской диссертации [1], который длился с 1.11.1961 по 30.04.1962, однако, по воспоминаниям родных, несмотря на возможность сосредоточится на написании диссертации, Александр Борисович все равно каждый день ходил на работу.

В 1961-1962 гг. появляются публикации работ по извлечению драгоценных металлов и урана из вод Атлантического океана. Синтез и исследование свойств селективных комплексообразующих ионообменников в лаборатории А.Б. Даванкова, позволили молодым сотрудникам принять участие в первых кругосветных плаваниях на научно-исследовательских судах. В результате была продемонстрирована принципиальная возможность селективного извлечения золота и урана из морской воды.

После кончины И.П. Лосева в мае 1963 г. и по 1969 кафедрой ТВМС заведовал ученик В.В. Коршака - Герман Сергеевич Колесников [15]. По-видимому, с этого времени «соперничество» между двумя «группами ионитчиков» прекращается.

В сборнике «Ионообменные сорбенты в промышленности» [52], изданном в 1963 г. помещены две статьи А.Б. Даванкова с сотрудниками. Статья совместно с Л.Б. Зубаковой посвящена описанию способа синтеза слабо и высокоосновных анионитов на основе сополимеров 2-метил-5-винилпиридина с дивинилбензолом и диметакриловым эфиром триэтиленгликоля [53]. Авторы отмечают высокую сорбционную способность синтезированных ими анионитов по отношению к фенолам. Вопросам применения ионообменных мембран в электродиализе посвящено несколько публикаций данного сборника. Статья А.Б. Даванкова и В.М. Лауфер «Об электрохимических процессах, осуществляемых на гранулированных ионитах» [54], показывает изменение направления работ группы Даванкова. Ссылаясь на свою работу по концентрированию золота на ионитах, с использованием вторичных процессов на нем, с одной стороны, а с другой на успешное использование ионообменных мембран и действие электрического поля на миграцию ионов (работа Е.Б. Тростянской и др.), авторы развивают идею концентрирования и десорбции благородных металлов на ионитах в электрическом поле. В работе представлена принципиальная схема лабораторной установки, в качестве сорбента применялся катионит КУ-2, отмечалось также, что ведутся исследования с применением «смолы, изготовленной на основе гидрохинона и формальдегида». Использование ионообменных мембран и действие электрического поля на миграцию ионов - то, чем будет заниматься Борис Николаевич Ласкорин с целью концентрирования ряда металлов, а в дальнейшем для обогащения урана, сделав на этом принципе мощную технологию, используемую и по сегодняшний день. Рассматриваемый сборник интересен тем, что отражает «палитру» научных групп, занятых изучением возможностей сорбентов для применения в различных промышленных производственных процессах. Есть публикации Харьковских специалистов - учеников физико-химика Н.А. Измайлова, шесть публикаций ИФХ (К.В. Чмутов, К.М. Ольшанова, Т.Б. Гапон и др.), пять публикаций Б.Н. Ласкорина и коллег, три К.М. Салдадзе, одна В.П. Мелешко и др.

К концу 1960-х гг. были синтезированы и запущены в массовое производство ионообменные сорбенты (в основном марок КУ и АВ, выпускаемых ВНИИПМ), ко- 
торые нашли широкое применение в промышленности. Однако, как отмечалось в аннотации к сборнику 1968 г. «Синтез и свойства ионообменных материалов», изданному ИФХ АН СССР: «Стандартные марки ионообменных смол иногда уже не удовлетворяют исследователя ни со стороны кинетических свойств и селективности, ни со стороны механической прочности и термостойкости». Часть работ данного сборника посвящена «поискам селективных сорбентов для разделения сложных смесей» [55]. Так, например, А.Б. Пашков с коллегами [56] развивает технологию хлорирования и хлормитилирования стирол-дивинилбензольных сополимеров при синтезе анионитов, в том числе со ссылкой на работу А.Б. Даванкова 1963 г. [57]. Сообщение А.Б. Даванкова, Л.Б. Зубаковой и А.А. Джабар [58] посвящено синтезу ряда новых амфотерных ионообменников и исследованию их свойств. В начале работы авторы отмечают, что амфотерные ионообменники «... используются при разделении органических соединений, сорбции стрепомицина и бензилпеницилина. А также могут применяться в качестве катализаторов многих химических реакций». В работе описывается синтез и исследуются свойства пяти марок амфотерных ионитов, доказывается наличие внутрисолевой связи в $\mathrm{Na}^{+}$и $\mathrm{OH}^{-}$формах амфолитов. Сборник интересен еще и тем, что там размещена одна из первых работ Вадима Александровича Даванкова (выполненная в лаборатории В.В. Коршака в ИНЭОС АН СССР), посвященная синтезу оптически активных ионитов [59]. Авторы отмечают малое число успешных разделений рацемических смесей, ссылаясь на пять зарубежных публикаций. Основная идея состоит в замене стандартного хлорметилирования - бром и иодметилированием сополимера стирола с дивинилбензолом, с последующим введением оптически активной аминокислотной группы. Полученные таким образом аниониты были исследованы для разделения оптических изомеров миндальной кислоты. В публикации Н.М. Кругликова и А.Б. Пашкова, посвященной синтезу окислительно-восстановительных сорбентов, упоминается работа А.Б. Даванкова [60] и Е.Б. Тростянской и А.С. Тевлиной [61] по извлечению ионообменниками благородных металлов.

О.Я. Федотова так пишет о лаборатории ионитов в 1960 гг.: «По проблеме работало в разное время 13 сотрудников. Исследования проводились в двух основных направлениях: 1) нерастворимые селективные комплесообразующие иониты; 2) растворимые полиэлектролиты». «Среди наиболее важных результатов ... явилась разработка растворимых полиэлектролитов, пригодных для извлечения благородных металлов из производственных растворов. Эта работа была внедрена на Московском монетном дворе, ряде ювелирных фабрик, на Томилинском заводе полупроводниковых приборов. Наряду с этим создан ряд ионитов полимеризационного типа, содержащих фосфор, для применения в гидрометаллургии, кино-фотопромышленности и в очистке сточных вод от фенолов». И далее: «К 1970 г. сформировались два основных научных направления: термостойкие полимеры и ионообменные материалы. ... исследования по синтезу и применению ионообменных материалов поликонденсаиионного и полимеризаиионного типов проводились по общему перспективному плану, составленному совместно с НИИПМ (руководители доц. А.Б. Даванков и доц. А.С. Тевлина)» [3, С.30-31].

Таким образом, подводя итог научной деятельности А.Б. Даванкова в области ионообменных материалов, можно утверждать, что начиная с середины 1940 гг. и до 1970 г. в лаборатории под его руководством разрабатывались принципиально новые технологические процессы синтеза ионообменных смол. В результате было создано более 60 отечественных марок ионитов, не только оригинальных анионообменников, но и первых амфотерных, комплексообразующих, электронообменных смол. Наиболее успешные из разработанных марок производились в МХТИ на полу- 
промышленной установке для использования: в научных исследованиях, в том числе для хроматографического анализа, концентрирования металлов и органических соединений, очистки промышленных сбросов, отработки технологических процессов перед передачей на производство. Ряд ионитов, уже под другими названиями, стали производить в промышленных масштабах. Разработки, связанные с оптимизацией технологических процессов, приносили колоссальный экономический эффект. Приведем только один, но наиболее показательный пример: внедрение в 1952 г. на Московском заводе «Галалит» нового непрерывного способа деполимеризации производственных отходов полиметилметакрилата по патенту А.Б. Даванкова [62] дало заводу более 0.5 миллиона рублей годовой экономии [1].

Александр Борисович Даванков - автор нескольких монографий и пособий, опубликовал около 200 научных статей, автор 61 изобретения. Работы, проводимые под руководством А.Б. Даванкова, многократно премировались на различных всесоюзных и институтских конкурсах, отмечались дипломами ВДНХ, грамотами Министерств высшего образования и химической промышленности. За большие заслуги в деле подготовки высококвалифицированных кадров для химической промышленности, за плодотворную научную деятельность А.Б. Даванков был награжден медалями «За доблестный труд во время Великой отечественной войны 1941-1945 гг.» (1945) и «В честь 800-летия Москвы», орденом Трудового Красного Знамени (1951), «Знаком отличника химической промышленности» (1950) и др.

А.Б. Даванков был прекрасным педагогом и наставником. С момента образования кафедры читал студентам курс технологии пластических масс, вел практикумы, руководил дипломными и аспирантскими работами. Его высокий педагогический уровень отмечен во многих отзывах и характеристиках, хранящихся в личном деле. А.Б. Даванков подготовил и выпустил в свет 14 кандидатов наук [63]. Подобно своим учителям - С.С. Наметкину, В.М. Родионову и А.М. Беркенгейму он делал акцент на практическое применение в промышленности результатов как своих работ, так и работ своих аспирантов. Бывая на предприятиях по всему Советскому Союзу, он часто брал аспирантов с собой, активно был вовлечен сам и привлекал их во внедрение в производство разработанных технологических процессов, за что неоднократно был отмечен благодарностями и поощрениями. С огромным талантом Александр Борисович писал популярную литературу об ионообменных материалах и их применении. Его книжечка «Волшебные зерна» [64], адресованная молодежи, читается как научно-популярный роман со всеми его атрибутами - прологом, интригой, развязкой и эпилогом; с реальными героями из прошлого и настоящего, со взглядом в будущее. Другая его книга - «Иониты» [65], может быть использована как учебное пособие, поскольку содержит массу фактического материала по научным исследованиям и практическим аспектам применения ионитов в различных отраслях промышленности. В книге представлено развитие химии и технологии ионитов в историческом аспекте, имеются схемы промышленных установок и рекомендуемый список дополнительной литературы для изучения. Эта книга интересна еще тем, что содержит описание разработок, выполненных лабораторией Даванкова, а также информацию на каких предприятиях эти технологии были реализованы.

В 1970 г. две «полимерные» кафедры МХТИ объединили в одну под руководством В.В. Коршака. Так в тот год уже тяжело больной Даванков писал о периоде параллельного существования двух кафедр под руководством Петрова и Лосева и об их объединении: «Те годы были очень тяжки, / Когда родилися двойняшки. /И тут для них в конце концов / Нашлась и парочка «отцов». .../ Две кафедры бок о бок жили, / Не ссорились и не дружили / И лишь отдельные годки / Точили малость когот- 
ки. /Что может быть нам в утешение? / Нашлося мудрое решенье: / Из кафедр двух сделать одну, /Вдвойне могучу и сильну».

Александр Борисович был исключительно добрым, скромным и отзывчивым человеком. О его прекрасных человеческих качествах написала его первая аспирантка и коллега, а также соавтор широко известной в среде ионообменщиков монографии «Синтетические ионообменные материалы» [66] - Людмила Борисовна Зубакова, доцент кафедры технологии пластмасс: «В группе ионитчиков, руководимой А.Б. Даванковым, всегда царила дружная деловая обстановка» [15]. «Невозможно умолчать об огромном оптимизме А.Б. Даванкова, о его любви к природе, к прекрасному, о неиссякаемом чувстве юмора, о его умении быть душой коллектива. Александр Борисович и неплохой поэт. Его юмористические стихи являются обязательной частью различных событий, дат, торжеств» [63]. Зубакова тоже писала стихи и посвятила ему такие строки:

«Был Александр Борисович с нами, / Наш дорогой учитель, славный друг /Всегда в работе, полон сил и знаний / Стихи напишет, если надо вдруг...». К 70-ти летию А.Б.Даванкова коллеги по лаборатории подготовили альбом с его стихами, снабженный прекрасными шаржами Татьяны Александровны Черкасовой последней аспирантки Даванкова.

Александ Борисович был страстным автомобилистом. В 1952 г., став членом Центрального московского спортивного авто-клуба, он вместе с семьей совершил первое большое путешествие Москва - Крым на автомобиле «Победа». В следующем году, уже набравшись опыта, семья Даванковых совершила два путешествия: Москва - Киев и Москва - Сухуми. Последнее путешествие сопровождала съемочная группа «Мосфильма». По воспоминаниям родных путешествие было полно удивительных приключений и положительных эмоций. $\mathrm{B}$ итоге вышел документальный фильм «Поедем в Сухуми», который демонстрировал широкой общественности высокий уровень культурного отдыха советских граждан.

Только родные и близкие Александра Борисовича знают, что он был одарен музыкально. Еще в молодости самостоятельно научился и с удовольствием играл на скрипке, пел под гитару. Вместе со своей супругой Антроповой Надеждой Ивановной часто организовывал домашние концерты - она аккомпонировала ему на пианино, а он играл на скрипке.

Александр Борисович ушел из жизни 13 января 1971 г., а его исследования продолжили ученики. Еще несколько лет после кончины выходили его публикации в соавторстве с учениками. В 1978 г. вышло учебное пособие для студентов, специализирующихся по ионообменным материалам, «Синтетические ионообменные материалы» в соавторстве с Л.Б. Зубаковой и А.С. Тевлиной [66]. В книге изложены основные сведения по химии и технологии ионообменных материалов промышленных марок; показаны главные направления синтеза перспективных ионитов; большое внимание уделено селективным ионитам, комплексообразующим и растворимым полиэлектролитам. Описаны физико-химические свойства ионитов.

В 1996 г. В.А. Гуровым и В.С. Ивановым был заявлен патент «Способ извлечения благородных металлов из растворов» [68], по существу являющийся оптимизацией технологий, разработанных в 1956-1957 гг. А.Б. Даванковым и В.М. Лауфер [68-70], что лишний раз доказывает, что даже спустя 40 лет эти технологии востребованы промышленностью и до настоящего времени сохраняют актуальность. 


\section{Список литературы}

1. Личное дело А.Б. Даванкова. (арх. МХТИ им. Д.И. Менделеева, оп. №9, св. 17, ед. хр. 131).

2. Кафедра ХТП. История и сегодняшний день. Сост. Л.Б. Зубакова. М. МХТИ им. Д.И. Менделеева, 2000. 73 с.

3. Федотова О.Я. История кафедры технологии пластических масс (1932-1995). Под ред. В.В. Киреева. М. МХТИ им Д.И. Менделеева. 1996. 47c.

4. Мошкин П.А., Даванков А.Б. Патент СССР, № 36403, 17.11.1930.

5. ХХ лет МХТИ им. Д.И. Менделеева. Под. Ред. И.Я. Пильского. М. Оборонгиз, $1940.112 \mathrm{c}$.

6. Федотова О.Я. Группа «окислителей». Газета «Менделеевец». №34 (1489), 14.12.1980.

7. Даванков А.Б., Григорьев А.П., Лосев И.П., Шишкин С.В. и др. Патент СССР. № 46012, 30.03.1935.

8. Петров Г.С., Даванков А.Б. Патент СССР. №50855., 03.12.1935.

9. Петров Г.С., Рутовский Б.Н., Лосев И.П. Технология синтетических смол и пластических масс. Л. Изд-во ГХИ. 1946. 548с.

10. Даванков А.Б., Антропова Н.И. Патент СССР. № 72196. 17.03.1940.

11. Даванков А.Б. Учебный практикум по химии целлюлозы и целлюлозных пластиков М. ГОНТИ. 1939. 236 с.

12. Профессор Григорий Семенович Петров - основоположник промышленности пластмасс России. Под. ред. акад. П.Д. Саркисова, проф. В.В. Кирева. Орехово-Зуево: РХТУ им. Д. И. Менделеева. 2006. 215 с.

13. Денисова Н.Ю., Жуков А.П. Эвакуация МХТИ им. Д. И. Менделеева в Коканд (19411943). М. РХТУ им. Д. И. Менделеева. 2012. $220 \mathrm{c}$.

14. Петров Г.С., Серб-Сербин П.В., Даванков А.Б. Патент СССР, № 66891. 05.11.1943.

15. Зубакова Л.Б. Доброе слово всем, кто рядом. М. РХТУ им. Д.И. Менделеева. 2003. $128 \mathrm{c}$.

16. Петров Г.С., Даванков А.Б., Лауфер В.М. Патент СССР., № 71615. 09.12.1946.

17. Прохоров Ф.Г. / В сб. Теория и практика применения ионообменных материалов. Под. ред. К.В. Чмутова. М. Изд-во АН СССР. 1955. С. 57-81.

18. Петров Г.С., Даванков А.Б., Лауфер В.М. Патент СССР. № 75513, 12.02.1948.
19. Петров Г.С, Даванков А.Б., Лауфер В.М. Патент СССР. № 77401, 21.10.1948.

20. Даванков А.Б. Патент СССР. № 77909. 10.11.1948.

21. Грибанов И.И., Даванков А.Б. Патент СССР. № 77806, 13.11.1948.

22. Даванков А.Б., Борзенкова С.Я. Патент СССР, № 81927, 4.07.1949.

23. Автобиография А.Б. Пашкова. Книга памяти. Сост. Чевардин В.В. Екатеринбург. Мемориал. 2003. 335 с.

24. Kunin R., Myers R.J. Ion-Exchange Resins. New York. Wiley. 1950. 212 p.

25. Кунин Р., Майерс Р. Ионообменные смолы. М. Ин. Лит. 1952. 215 с.

26. Сенченкова Е.М. // Теория и практика сорбиионных процессов. 1999. Т. 25. С. 8-20.

27. Исследования в области хроматографии. Труды всесоюзного совещания по хроматографии 21-24.11.1950. Под ред. М.М. Дубинина М. Изд. АН СССР, 1952. 225 с.

28. Даванков А.Б. / В сб. «Исследования в области хроматографии». Под ред. Дубинина М.М. М. Изд. АН СССР. 1952. С. 107-113.

29. Лосев И.П., Тростянская Е.Б., Тевлина А.С. / В сб. «Исследования в области хроматографии». Под ред. Дубинина М.М. М. Изд. АН СССР. 1952. С. 103-106.

30. Салдадзе К.М. / В сб. «Исследования в области хроматографии». Под ред. Дубинина М.М. М. Изд. АН СССР, 1952. С. 114-126.

31. Даванков А.Б. Огнева Н.Е. // Гигиена и санитария.1954. № 2. С. 9.

32. Теория и практика применения ионообменных материалов. Под ред К.В. Чмутова. М. Изд-во АН СССР. 1955. 164 с.

33. Даванков А.Б. / В сб. Теория и практика применения ионообменных материалов. Под ред. К.В. Чмутова. М. Изд-во АН СССР. 1955. С. 126-134.

34. Тростянская Е.Б., Лосев И.П. / В сб. Теория и практика применения ионообменных материалов. Под. ред. К.В. Чмутова. М. Изд-во АН СССР. 1955. С. 28-34.

35. Лосев И.П., Тевлина А.С., Тростянская Е.Б. / В сб. Теория и практика применения ионообменных материалов. Под. ред. К.В. Чмутова. М.: Изд-во АН СССР. 1955. С. 3540.

36. Апельцин А.В., Клячко В.А., Лурье Ю.Ю., Смирнов А.С. Иониты и их применение. М. Стандартгиз. 1949. 256 с. 
37. Лосев И.П., Тевлина А.С. / В сб. Теория и практика применения ионообменных материалов. Под. ред. К.В. Чмутова. М. Изд-во АН СССР. 1955. С 156-159.

38. Даванков А.Б., Вехец Т. Патент СССР. № 105757, 05.03.1956.

39. Даванков А.Б., Лауфер В.М. // Зав. лаб. 1956, 22, №3, С.294; 22, №7 C. 788.

40. Исследования в области ионообменной хроматографии. Труды Совещания по применению ионообменной хроматографии в медицинской и пищевой промышленности. Отв. Ред. К.В. Чмутов, Ф.М. Шемякин. М. Изд-во АН СССР. 1957. 200 с.

41. Даванков А.Б., Лауфер В.М. / В сб. Исследования в области ионообменной хроматографии. М. Изд-во АН СССР. 1957. С. 127133.

42. Салдадзе К.М., Демонтерик З.Г., Климова 3.В. / В сб. Исследования в области ионообменной хроматографии. М. Изд-во АН CCCP. 1957. C. 48-54.

43. Тростянская Е.Б., Тевлина А.С. / В сб. Исследования в области ионообменной хроматографии. М. Изд-во АН СССР. 1957. С. 117-126.

44. Даванков А.Б. Григорий Семенович Петров. М. МХТИ им. Д.И. Менделеева. 1959. $32 \mathrm{c}$.

45. Копылова (Валова) В.Д., Меквабишвили Т.В. // Сорбиионные и хроматографические проиессы. 2013. Т. 13. № 3. С. 401-403.

46. Титов В.С., Шостак Ф.Т., Самборский И.В., Салдадзе К.М. и др. Патент СССР, № 116084. 25.04.1958.

47. Тростянская Е.Б. / Сб. Ионный обмен и его применение. М. Изд-во АН СССР. 1959. C. 11-83.

48. Исследования в области промышленного применения сорбентов. Отв. ред. К.В. Чмутов. М. Изд-во АН СССР. 1961. 232 с.

49. Даванков А.Б., Замбровская Е.В. / Сб. Исследования в области промышленного применения сорбентов. Отв. ред. К.В. Чмутов. М. Изд-во АН СССР. 1961. С. 27-30.

50. Даванков А.Б., Иосилевич А.И., Лауфер В.М. Патент СССР, № 132618, 16.11.1959.

51. Даванков А.Б., Лауфер В.М. / Сб. Исследования в области промышленного применения сорбентов. Отв. ред. К.В. Чмутов. М. Изд-во АН СССР. 1961. С. 197-201.

52. Ионообменные сорбенты в промышленности. Отв. ред. К.В. Чмутов. М. Изд-во АН СCCР. 1963. 244 c.
53. Даванков А.Б., Зубакова Л.Б. / Сб. Ионообменные сорбенты в промышленности. Отв. ред. К.В. Чмутов. М. Изд-во АН СССР. 1963. С. 38-42.

54. Даванков А.Б., Лауфер В.М. / Сб. Ионообменные сорбенты в промышленности. Отв. ред. К.В. Чмутов. М. Изд-во АН СССР. 1963. С. $38-42$.

55. Синтез и свойства ионообменных материалов. Сб. под ред. К.В. Чмутова. М. Наука. $1968.320 \mathrm{c}$.

56. Иткина М.И., Журавлева М.А., Пашков А.Б., Куинджи Б.М. и др. / Сб. Синтез и свойства ионообменных материалов. Под ред. К.В. Чмутова. М. Наука. 1968. С. 13-17.

57. Даванков А.Б., Витол О.А. // Журн. высокомолекулярные соединения. 1963. №10. С. 21.

58. Даванков А.Б., Зубакова Л.Б., Джабар А.А. / Сб. Синтез и свойства ионообменных материалов. Под ред. К.В. Чмутова. М. Наука. 1968. С. 44-48.

59. Коршак В.В., Рогожин С.В., Даванков В.А., Маслов Л.А. / Сб. Синтез и свойства ионообменных материалов. Под ред. К.В. Чмутова. М. Наука. 1968. С. 49-53.

60. Даванков А.Б., Аптова Т.А., Гитерман 3.М. // Журн. прикл. химии. 1961. Т. 34. № 8. C. 1852-1857.

61. Тростянская Е.Б., Тевлина А.С. // Журнал аналитической химии. 1960. Т. 15. Вып. 4. C. 402-404.

62. Даванков А.Б. Лекае В.М. Патент СССР, № 73501. 9.02.1948.

63. Зубакова Л., Лейкин Ю. Заслуженный юбилей. Газета «Менделеевец». №8(1053). 18.03.1969.

64. Даванков А.Б. Волшебные зерна М. Изд-во Молодая гвардия. 1960. 61с.

65. Даванков А.Б. Иониты. М. Изд-во Знание. серия Химия. 1970. 46 c.

66. Зубакова Л.Б. Тевлина А.С., Даванков А.Б. Синтетические ионообменные материалы. М. Химия. 1978. 184c.

67. Гуров В.А., Иванов В.С. Патент РФ. 2095443. 09.03.1996.

68. Даванков А.Б., Лауфер В.М., Шиц Л.А. // Журнал прикладной химии. 1957. Т. 30. Вып. 6. С. 839-844.

69. Даванков А.Б., Лауфер В.М. // Изв. Вузов. Цветная металлургия. 1961. № 4. С. 121-123.

70. Даванков А.Б., Лауфер В.М. // Зав. лаб. 1956. Т. 22. № 7. С. 788-789. 


\section{References}

1. Personal file of A.B. Davankov. (arkh. MHTI named D.I Mendeleev, op. No 9. sv. 17, 131).

2. Kafedra HTP. Istoriya i segodnyashniy den. L.B. Zubakova. Moscow, MHTI named D.I. Mendeleev, 2000, 73 p.

3. Fedotova O.Y. Istoriya kafedry technologii plastmass (1932-1995). Edit by V.V. Kireev. M., MHTI named D.I. Mendeleev, 47 p.

4. Moshkin P.A., Davankov A.B. Patent of the USSR, No 36403, 17.11.1930.

5. XX let MHTI im. D.I. Mendeleeva. Edit by I.Y. Pilsky. Mo., Oborongiz, 1940, 112 p.

6. Fedotova O.Y. Gruppa "okisliteley". Mendeleevets newspaper, No 34 (1489), 14.12.1980.

7. Davankov A.B., Grigoriev A.P., Losev I.P., Shishkin S.V. et al., Patent of the USSR, No 46012, 30.03.1935.

8. Petrov G.S., Davankov A.B. Patent of the USSR, No. 50855, 03.12.1935.

9. Petrov G.S., Rutovsky B.N., Losev I. P. Technologiay sintheticheskikh smol i plasticheskikh mass. Leningrad, GHI, 1946, 548 p.

10. Davankov A.B., Antropova N.I. Patent of the USSR, No 72196, 17.03.1940.

11. Davankov A.B. Uchebnyi praktikum po chimii cellulozy i cellulosnykh plastikov. M., GONTI, 1939, $236 \mathrm{p}$.

12. Professor Grigory Semyonovich Petrov osnovopolognik promyshlennosti plastmass Rossii. Edit by acad. P.D. Sarkisov, prof. V.V. Kirev. Orekhovo-Zuyevo: RHTU named D.I. Mendeleev, 2006, 215 p.

13. Denisova N.Y., Zhukov A.P. Evakuaziya MHTI v Kokand (1941-1943). M., RHTU of D.I. Mendeleyev, 2012, 220 p.

14. Petrov G.S., Serb-Serbin P.V., Davankov A.B. Patent of the USSR, No 66891, 05.11.1943.

15. Zubakova L.B. Dobroe slovo vsem kto rydom. M., RHTU named Mendeleev, 2003, $128 \mathrm{p}$.

16. Petrov G.S., Davankov A.B., Laufer V.M. Patent of the USSR, No 71615, 09.12.1946.

17. Prokhorov F.G. / In «Theory and practice of use of ion-exchange materials." Edit by K.V. Chmutov, M., Academy of Sciences of the USSR, 1955, pp. 57-81.
18. Petrov G.S., Davankov of A.B., Laufer V.M. Patent of the USSR, No 75513, 12.02.1948.

19. Petrov G. With, Davankov A.B., Laufer V.M. Patent of the USSR, No 77401, 21.10.1948.

20. Davankov A.B. Patent of the USSR, No 77909, 10.11.1948.

21. Gribanov I.I., Davankov A.B. Patent of the USSR, No 77806, 13.11.1948.

22. Davankov A.B., Borzenkova S.Y. Patent of the USSR, No 81927, 4.07.1949.

23. Autobiography of A.B. Pashkov. Book of memory. Collected by Chevardin V.V., Yekaterinburg: Memorial, 2003, 335 p.

24. Kunin R., Myers R.J. Ion-Exchange Resins, New York, Wiley, 1950, 212 p.

25. Kunin R., Myers River., Ion-exchange pitches, M., Ying. Litas, 1952, 215 p.

26. Senchenkova E.M. // Teoriya i praktika sorptsionnykh protsessov, 1999, Vol. 25, pp. 820.

27. Issledovaniya $\mathrm{v}$ oblasti khromatografii. Edit by M.M. Dubinin, M., Academy of Sciences of the USSR, 1952, $225 \mathrm{p}$.

28. Davankov A.B. / In «Issledovaniya v oblasti khromatografii». Edit by M.M. Dubinin, M., Academy of Sciences of the USSR, 1952, pp. 107-113.

29. Losev I.P., Trostyanskaya E.B., Tevlina A.S. / In «Issledovaniya v oblasti khromatografii». Edit by M.M. Dubinin Moscow, Academy of Sciences of the USSR, 1952, pp. 103-106.

30. Saldadze K.M. / In «Issledovaniya v oblasti khromatografii». Edit by M.M. Dubinin Moscow, Academy of Sciences of the USSR, 1952, pp. 114-126.

31. Davankov A.B. Ogneva N.E. // Zh. Gygiena $i$ sanitariya, 1954, No 2, P. 9.

32. Theoria i praktika ispol'zovaniya ionoobmennykh materialov, Edit by K.V. Chmutov, M., Academy of Sciences of the USSR, 1955, $164 \mathrm{p}$.

33. Davankov A.B. / In «Theoria i praktika ispol'zovaniya iono-obmennykh materialov». Edit by K.V. Chmutov, M., Academy of Sciences of the USSR, 1955, pp.126-134.

34. Trostyanskaya E.B., Losev I.P. / In «Theoria i praktika ispol'zovaniya ionoobmennykh materialov». Edit by K.V. Chmutov. Moscow, Academy of Sciences of the USSR, 1955, pp. 28-34. 
35. Losev I. P., Tevlina A. S., Trostyanskaya E.B. / In «Theoria i praktika ispol'zovaniya iono-obmennykh materialov». Edit by K.V. Chmutov, M., Academy of Sciences of the USSR, 1955, pp. 35-40.

36. Apeltsin A.V., Klyachko VA., Lurye Y.Y., Smirnov A.S. Ionity i ikh primenenie, M., Standartgiz, 1949.

37. Losev I.P., Tevlina A.S. / In «Theoria i praktika ispol'zovaniya iono-obmennykh materialov». Edit by K.V. Chmutov. M., Academy of Sciences of the USSR, 1955, pp. 156-159.

38. Davankov A.B., Vekhets T. Patent of the USSR, No 105757, 05.03.1956.

39. Davankov A.B., Laufer V.M. // J. Zav. lab. 1956, 22, No. 3, P. 294; 22, No. 7 of P. 788.

40. Issledovaniya $\mathrm{v}$ oblasti iono-obmennoi khromatografii. Edit by K.V. Chmutov, F.M. Shemyakin, M., Academy of Sciences of the USSR, 1957, $200 \mathrm{p}$.

41. Davankov A.B., Laufer V.M. / In «Issledovaniya $\mathrm{v}$ oblasti iono-obmennoi khromatografii». Edit by K.V. Chmutov, F.M. Shemyakin. Moscow, Academy of Sciences of the USSR, 1957, pp. 127-133.

42. Saldadze K.M., Demonterik Z.G., Klimova Z.V. / In «Issledovaniya v oblasti ionoobmennoi khromatografii». Edit by K.V. Chmutov, F.M. Shemyakin. Moscow, Academy of Sciences of the USSR, 1957, pp. 48-54.

43. Trostyanskaya E.B., Tevlina A.S. / In «Issledovaniya v oblasti iono-obmennoi khromatografii». Edit by K.V. Chmutov, F.M. Shemyakin, M., Academy of Sciences of the USSR, 1957, pp. 117-126.

44. Davankov A.B., Grigory Semyonovich Petrov, M., MHTI named D.I.Mendeleev, 1959, $32 \mathrm{p}$.

45. Kopylova (Valova) V. D., Mekvabishvili T.V. I/ Sorbtsionnye I khromatograficheskie protsessy, 2013, Vol. 13, No 3, pp. 401-403.

46. Titov V.S., Shostak of F.T., Samborsky I.V., Saldadze K.M. et al., Patent of the USSR, No 116084, 25.04.1958.

47. Trostyanskaya E.B. / In «Ionnyi obmen i ego primenenie», M., Academy of Sciences of the USSR, 1959, pp. 11-83.

48. Issledovaniya $\mathrm{v}$ oblasti promyshlennogo primeneniya sorbentov,. Edit by K.V. Chmutov, M., Academy of Sciences of the USSR, 1961, $232 \mathrm{p}$.

49. Davankov A.B., Zambrovskaya E.V. / In «Issledovaniya $\mathrm{v}$ oblasti promyshlennogo primeneniya sorbentov», Edit by K.V. Chmutov,
M., Academy of Sciences of the USSR, 1961, pp. 27-30.

50. Davankov A.B., Iosilevich A.I., Laufer V.M., Patent of the USSR, No 132618, 16.11.1959.

51. Davankov A.B., Laufer V.M. / In «Issledovaniya $\mathrm{v}$ oblasti promyshlennogo primeneniya sorbentov», Edit by K.V. Chmutov, M., Academy of Sciences of the USSR, 1961, pp. 197-201.

52. Iono-obmennye sorbenty $\mathrm{v}$ promyshlennosti, Edit by K.V. Chmutov, M., Academy of Sciences of the USSR, 1963, $244 \mathrm{p}$.

53. Davankov A.B., Zubakova L.B. / In «Ionoobmennye sorbenty v promyshlennosti», Edit by K.V. Chmutov, M., Academy of Sciences of the USSR, 1963, pp. 38-42.

54. Davankov A.B., Laufer V.M. / In «Ionoobmennye sorbenty v promyshlennosti». Edit by K.V. Chmutov. M., Academy of Sciences of the USSR, 1963, pp. 38-42.

55. Syntez i svoystva ionoobmennykh materialov, Edit by K.V. Chmutov, M., Nauka, 1968, $320 \mathrm{p}$.

56. Itkina M.I., Zhuravleva M.A., Pashkov A.B., Kuindzhi B.M. et al., In «Syntez i svoystva iono-obmennykh materialov», Edit by K.V. Chmutov, M., Nauka, 1968, pp. 13-17.

57. Davankov A.B., Vitol O.A., Zh. VMS, 1963, No 10, P. 21.

58. Davankov A.B., Zubakova L.B., Jabar A.A., In «Syntez i svoystva iono-obmennykh materialov», Edit by K.V. Chmutov, M., Nauka, 1968, pp. 44-48.

59. Korshak V.V., Rogozhin S.V., Davankov V. A., Maslov L.A., In «Syntez i svoystva ionoobmennykh materialov», Edit by K.V. Chmutov, M., Nauka, 1968, pp. 49-53.

60. Davankov A.B., Aptova T.A., Giterman Z.M. // Zh prikl. Khimii, 1961, Vol. 34, No 8, pp. 1852-1857.

61. Trostyanskaya E.B., Tevlina A.S., Zh. Anal. Khimii, 1960, Vol. 15, No 4, pp. 402-404.

62. Davankov of A.B. Lekaye V.M. Patent of the USSR, No 73501, 9.02.1948.

63. Zubakova L., Leykin Y., Zaslugennyi yubiley. Mendeleevets newspaper, No. 8(1053). 18.03.1969.

64. Davankov A.B., Volshebnyie zerna, M., Molodaya gvardiya, 1960, $61 \mathrm{p}$.

65. Davankov A.B., Ionity, M., Znaniye, ser. Khomiya, 1970, 46 p.

66. Zubakova L.B. Tevlina A. S., Davankov A.B., Syntheticheskie iono-obmennye materialy, M., Khimiya, 1978, 184 p. 
67. Gurov V.A., Ivanov V.S., Patent of the Russian Federation, 2095443, 09.03.1996.

68. Davankov A.B., Laufer V.M., Shits L.A.,Zh. Anal. Khimii, 1957, Vol. 30, No 6, pp. 839-844.

Рыбакова Елена Вениаминовна - соискатель ИИЕТ им. С.И. Вавилова РАН, зам.главы МПО «Абакус», Москва
69. Davankov A.B., Laufer V.M., Izv. vuzov. Cvetnaya metallurgiya, 1961, No 4, pp. 121123.

70. Davankov A.B., Laufer V.M., Zh. Zav. lab., 1956, Vol. 22, No 7, pp. 788-789.

Rybakova Elena V. - the applicant, Institute of history of sciences and equipment, named S.I. Vavilov, Deputy head of MRO «Abacus», Moscow, email: rybakova_elena@list.ru 